\title{
Pengaruh Penggunaan Plastik Sekali Pakai Terhadap Polusi Di Lingkungan SD 081/IX Air Itam Kabupaten Muaro Jambi
}

\author{
Ponirah \\ SD 081/IX Air Itam Kabupaten Muaro Jambi \\ Correspondance email: Sd81@gmail.com
}

\begin{abstract}
Abstrak. Penelitian ini dilakukan di SD 081 / IX Air Itam. Penelitian ini bertujuan untuk mengetahui pengaruh penggunaan plastik sekali pakai terhadap pencemaran lingkungan. Metode yang digunakan adalah metode kuantitatif. Teknik pengumpulan data menggunakan data primer berupa tes pengetahuan tentang pemanfaatan sampah plastik sekali pakai dan pencemaran di SD 081 / IX Air Itam. Populasi dalam penelitian ini adalah siswa kelas V dan VI SD 081 / IX Air Itam yang berjumlah 97 siswa. Teknik analisis data dalam penelitian ini menggunakan teknik analisis regresi linier sederhana dengan menggunakan SPSS versi 24.0, dengan ketentuan $\mathrm{Sig}<\alpha(0,05), \mathrm{H} 0$ ditolak dengan H1 diterima (koefisien regresi signifikan). Sig $>\alpha(0,05)$, H0 diterima dan H1 ditolak (koefisien regresi tidak signifikan). Hasil penelitian secara keseluruhan variabel X (Penggunaan plastik sekali pakai) mayoritas responden mendapat skor 57-73 atau 60,82\% dari jumlah responden. Artinya penggunaan plastik sekali pakai untuk kelas V dan VI SD 081 / IX Air Itam sudah cukup baik. Pada variabel Y (Pencemaran Lingkungan) skor 74-100 atau 94,84\%. Artinya pemahaman tentang pencemaran lingkungan di SD 081 / IX Air Itam sudah cukup baik.
\end{abstract}

Kata Kunci: Sampah Plastik - Pencemaran Lingkungan

\begin{abstract}
SD 081 / IX Air Itam. This research aims to determine the effect of using single-use plastics on environmental pollution. The method used is a quantitative method. The data collection technique used primary data in the form of a test of knowledge about the use of single-use plastic waste and pollution in SD 081 / IX Air Itam. The population in this study were students of class V and VI SD 081 / IX Air Itam, totaling 97 students. Data analysis techniques in this study using simple linear regression analysis techniques using SPSS version 24.0, with the provisions of Sig $<\alpha(0.05)$, $H_{0}$ is rejected with $H_{1}$ accepted (significant regression coefficient). Sig $>\alpha$ (0.05), $H_{0}$ is accepted and $\mathrm{HI}$ is rejected (the regression coefficient is not significant). The results of the overall research $X$ variable (Use of single-use plastic) the majority of respondents got a score of 57 to 73 or $60.82 \%$ of the number of respondents. This means that the use of single-use plastics for grade V and VI SD 081 / IX Air Itam is quite good. In the Y variable (Environmental Pollution) scores 74-100 or 94.84\%. This means that the understanding of pollution in the environment at SD 081 / IX Air Itam is quite good.
\end{abstract}

Keywords: Plastic Waste - Environmental Pollution

\section{PENDAHULUAN}

Pengertian Polusi yaitu masuknya atau dimasukkannya makhluk hidup, zat energi, dan atau komponen lain ke dalam lingkungan, atau berubahnya tatanan lingkungan oleh kegiatan manusia atau oleh proses alam sehingga kualitas lingkungan turun sampai ke tingkat tertentu yang menyebabkan lingkungan menjadi kurang atau tidak dapat berfungsi lagi sesuai dengan peruntukannya (Undang-undang Pokok Pengelolaan Lingkungan Hidup No. 4 Tahun 1982). Polutan adalah Zat atau bahan yang dapat mengakibatkan pencemaran terhadap lingkungan baik (Pencemaran Udara, Tanah, Air).

Polusi atau pencemaran lingkungan adalah masuknya atau dimasukkannya makhluk hidup, zat energi, dan atau komponen lain ke dalam lingkungan, atau berubahnya tatanan lingkungan oleh kegiatan manusia atau oleh proses alam sehingga kualitas lingkungan turun sampai ke tingkat tertentu yang menyebabkan lingkungan menjadi kurang atau tidak dapat berfungsi lagi sesuai dengan peruntukannya. Syarat-syarat suatu zat disebut polutan bila keberadaannya dapat menyebabkan kerugian terhadap makhluk hidup. Contohnya, karbon dioksida dengan kadar 0,033\% di udara berfaedah bagi tumbuhan, tetapi bila lebih tinggi dari 0,033\% dapat rnemberikan efek merusak. Menurut Undang Undang No. 23 Tahun 1997, lingkungan hidup adalah kesatuan ruang dengan semua benda, daya, keadaan, dan makhluk hidup, termasuk manusia dan perilakunya, yang mempengaruhi kelangsungan perikehidupan dan kesejahteraan manusia serta makhluk hidup lain. Sedangkan ruang lingkup lingkungan hidup Indonesia meliputi ruang, tempat Negara Kesatuan Republik Indonesia yang berwawasan Nusantara dalam melaksanakan kedaulatan, hak berdaulat, dan yurisdiksinya (Arya Wisnu : 2009).

Pencemaran menurut SK Menteri Kependudukan Lingkungan Hidup No 02/MENKLH/1988, adalah masuk atau dimasukkannya mahluk hidup, zat,energi, dan/atau komponen lain ke dalam air/udara, dan/atau berubahnya tatanan (komposisi) air/udara oleh kegiatan manusia dan proses alam, sehingga kualitas air/udara menjadi kurang atau tidak dapat berfungsi lagi sesuai dengan peruntukkannya. 
Untuk mencegah terjadinya pencemaran terhadap lingkungan oleh berbagai aktivitas industri dan aktivitas manusia, maka diperlukan pengendalian terhadap pencemaran lingkungan dengan menetapkan baku mutu lingkungan. Baku mutu lingkungan adalah batas kadar yang diperkenankan bagi zat atau bahan pencemar terdapat di lingkungan dengan tidak menimbulkan gangguan terhadap makhluk hidup, tumbuhan atau benda lainnya.

Pada saat ini, pencemaran terhadap lingkungan berlangsung di mana-mana dengan laju yang sangat cepat.Sekarang ini beban pencemaran dalam lingkungan sudah semakin berat dengan masuknya limbah industri dari berbagai bahan kimia termasuk logam berat serta plastik minuman sekali pakai. Sampah merupakan sesuatu yang tidak pernah lepas dari kehidupan manusia. Gaya hidup dan lingkungan membuat manusia terus menerus membutuhkan barang untuk memenuhi kebutuhan dan keinginannya. Tanpa disadari miliaran ton sampah ditinggalkan begitu saja di TPA menjadi timbunan, laut dan sungai tercemar. Data dari Perusahaan Daerah (PD) Kebersihan Kota Bandung, Kota Bandung memiliki 2.5 juta jiwa penduduk yang setiap harinya menghasilkan 1500 sampai 1600 ton sampah. Dari jumlah ini, 48\% adalah sampah non organik yang memiliki waktu panjang untuk terurai. Hal ini diperburuk oleh sistem daur ulang dan pengelolaan sampah yang banyak terkendala oleh sarana dan prasarana. Menyebabkan sebagian sampah non organik ini tercampur dengan sampah organik dan berakhir menjadi timbunan di tempat pembuangan akhir atau tercecer di lingkungan sehingga menimbulkan masalah seperti pencemaran lingkungan yang berbahaya bagi kesehatan, masa operasional TPA yang singkat serta tingginya biaya pengelolaan sampah itu sendiri.

Berlakunya UU No 18 Tahun 2008 tentang pengelolaan sampah, seharusnyabisa mendorong kerjasama antara masyarakat dan Lembaga pemerintah terkait untuk mengelola sampah secara bersama dan mengurangi timbulan sampah langsung dari sumbernya. Namun pada praktik di lapangan, pengetahuan masyarakat Kota Bandung terutama generasi muda tentang permasalahan sampah masih sangat rendah menyebabkan kurangnya partisipasi dan kepedulian terhadap permasalahan sampah. Selain itu gaya hidup generasi muda yang tinggal sendiri di perkotaan cenderung ingin serba cepat dan instan sehingga mereka banyak memakai produk yang terbuat dari plastik yang bersifat sekali pakai juga membuatjumlah timbulan sampah semakin besar. Data dari PD Kebersihan Kota Bandung setidaknya $18.5 \%$ komposisi sampah Kota Bandung merupakan sampah plastik. Kondisi seperti ini yang menuntut perubahan pola pikir masyarakat terhadap sampah sampah plastik dan tak hanya mengandalkan pemerintah. Perubahan perilaku generasi muda dalam menggunakan plastik sekali pakai harus diubah dari

\section{METODE}

Metode penelitian yang digunakan adalah kuantitatif. Popolasi dalam penelitian ini adalah siswa kelas V dan VI SD 081/IX AIR ITAM yang berjumlah 97 siswa. Penelitian ini dilaksanakan pada tahun 2018.

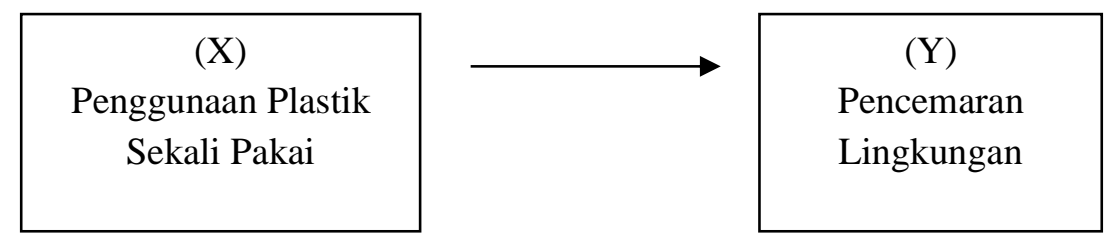

\section{Teknik Pengumpulan Data}

Pengumpulan data yang digunakan dalam penelitian ini berupa data primer, dengan cara membagikan soal tes tentang penggunaan plastik sekali pakai dan pengaruh pencemaran lingkungan dengan menggunakan skala Guttman dengan skor 1 apabila jawaban benar dan skor 0 apabila jawaban salah. Untuk mengetahui tingkat penggunaan plastik sekali pakai terhadap pencemaran lingkungan. Dalam pengisian kuesioner menggunakan skala likert untuk mengetahui bagaimana pengaruh penggunaan plastik sekali pakai terhadap pencemaran lingkungan (Iskandar : 2009).

\section{Teknik Analisis Data}

Tehnik analisis data dalam penelitian ini dengan menggunakan tehnik analisis regresi linear sederhana menggunakan SPSS versi 24.0, dengan ketentuan Sig $<\alpha(0,05)$, H0 ditolak dengan $\mathrm{H}_{1}$ diterima (koefisien regresi signifikan). $\mathrm{Sig}>\alpha(0,05), \mathrm{H}_{0}$ diterima dan $\mathrm{H}_{1}$ ditolak (koefisien regresi tidak signifikan) (Hadari, Nawawi : 1995).

\section{HASIL DAN PEMBAHASAN}

Berdasarkan hasil penelitian tentang pengaruh penggunaan plastik sekali pakai terhadap pencemaran lingkungan siswa kelas V dan IV SD 081/IX AIR ITAM yang berjumlah 97 siswa. Hasil penelitian keseluruhan variabel X (Penggunaan Plastik Sekali Pakai) mayoritas responden mendapat nilai 57 sampai 73 atau sebesar 60,82\% dari jumlah responden. Hal ini dapat diartikan bahwa penggunaan plastik sekali pakai pada siswa kelas V dan VI SD 081/IX AIR ITAM terbilang cukup baik. Pada variabel Y (Pencemaran Lingkungan) mendapat nilai 74-100 atau 
sebesar 94,84\%. Hal ini dapat diartikan bahwa pemahaman tentang polusi di lingkungan di SD 081/IX AIR ITAM terbilang cukup baik.

Uji normalitas residual digunakan untuk menguji apakah nilai residual yang dihasilkan dari regresi terdistribusi secara normal atau tidak dengan menggunakan One Sample Kolmogorov-Smirnov Test, nilai signifikansi Asymp, Sig. (2-tailed) sebesar 0,2 lebih besar dari 0,05. Maka sesuai dengan dasar pengambilan keputusan dalam uji normalitas Kolmogorov-Smirnov dapat disimpulkan bahwa data berdistribusi normal dan persyaratan normalitas dalam model regresi telah terpenuhi. Uji heteroskedastisitas adalah varian residual yang tidak sama pada semua pengamatan di dalam model regresi. Berdasarkan hasil pengelolaan data regresi linear sederhana, maka diperoleh persamaan regresi sederhana pengaruh penggunaan plastik sekali pakai terhadap pencemaran lingkungan menghasilkan koefisien arah

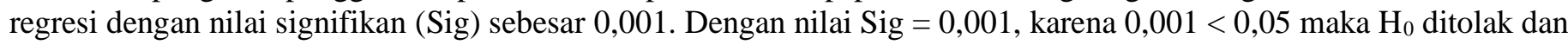
$\mathrm{H}_{1}$ diterima, hal ini menandakan bahwa terdapat pengaruh yang signifikan dari penggunaan plastik sekali pakai terhadap polusi lingkungan.

Berdasarkan data yang diperoleh bahwa persamaan regresi diketahui nilai konstanta sebesar 53,844, sedangkan angka koefisien regresi nilainya sebesar $-0,860$. Angka ini mengandung pengertian bahwa setiap penambahan $1 \%$ tingkat penggunaan plastik $(\mathrm{X})$, maka polusi $(\mathrm{Y})$ akan menurun 0,860 , sehingga memiliki persamaan regresi yaitu $\mathrm{Y}=$ $\mathrm{a}+\mathrm{bX}$ atau $\mathrm{Y}=53,844-0,860 \mathrm{X}$. Sedangkan berdasarkan hasil perhitungan uji-t, diperoleh $\mathrm{t}$ hitung sebesar 3,545. Dengan nilai $\mathrm{t}$ tabel $\mathrm{df}=\mathrm{n}-2=97-2=95$ adalah 1,985. Dari perhitungan nilai $\mathrm{t}$ hitung $>\mathrm{t}$ tabel $(3,545>1,985)$, maka $\mathrm{H}_{\mathrm{o}}$ diterima dan $\mathrm{H}_{1}$ ditolak, sehingga dapat disimpulkan bahwa terdapat pengaruh yang signifikan antara polusi lingkungan terhadap plastik sekali pakai.

\section{SIMPULAN}

1. Berdasarkan hasil penelitian tentang pengaruh penggunaan plastik sekali pakai terhadap pencemaran lingkungan siswa kelas V dan IV SD 081/IX AIR ITAM yang berjumlah 97 siswa. Hasil penelitian keseluruhan variabel X (Penggunaan Plastik Sekali Pakai) mayoritas responden mendapat nilai 57 sampai 73 atau sebesar 60,82\% dari jumlah responden. Hal ini dapat diartikan bahwa penggunaan plastik sekali pakai pada siswa kelas V dan VI SD 081/IX AIR ITAM terbilang cukup baik.

2. Pada variabel Y (Pencemaran Lingkungan) mendapat nilai $74-100$ atau sebesar $94,84 \%$. Hal ini dapat diartikan bahwa pemahaman tentang polusi di lingkungan di SD 081/IX AIR ITAM terbilang cukup baik.

3. Berdasarkan data yang diperoleh bahwa persamaan regresi diketahui nilai konstanta sebesar 53,844, sedangkan angka koefisien regresi nilainya sebesar $-0,860$.

\section{Saran}

1. Diharapkan kepada semua pihak khususnya Dinas Pendidian Kabupaten Muaro Jambi untuk lebih mengadakan sosialisasi akan pentingnya pemahaman tentang penggunaan sampah plastik terhadap terjadinya polusi.

2. Kepada pihak sekolah hendaknya memperbanyak tempat pembuangan sampah serta dapat memisahkan antara sampah organik dan non organik.

\section{DAFTAR PUSTAKA}

Arya, Wisnu. 2009. Dampak Pencemaran Lingkungan. Jakarta : Andi Publisher

Fandiaz, Sirkandi. 1992. Polusi Air dan Udara. Jakarta : Kanisius

Hadari, Nawawi. 1995. Metodologi Penelitian Bidang sosial. Yogyakarta : UGM

Hamzah. 2012. Teori Motivasi dan Pengukurannya. Jakarta : PT Bumi Aksara

Iskandar. 2009. Metodologi Penelitian Pendidikan dan Sosial (Kuantitatif dan Kualitatif). Jakarta : Gaung Persada Press

Martinis Yamin. 2012. Paradigma Baru Pembelajaran. Jakarta : Referensi

Nana, Sujdana. 1999. Tuntunan Penyusunan Karya Ilmiah. Bandung : Sinar Baru Algensindo 